\title{
In vivo CNS Depressant and Antinociceptive Studies of Microcos paniculata Stem Extracts on Animal Model
}

\author{
Md. Anamul Haque ${ }^{1}$, Md. Anwarul Haque ${ }^{2}$ and Md. Anwar Ul Islam² \\ ${ }^{1}$ Department of Pharmacy, Comilla University, Comilla, Bangladesh \\ ${ }^{2}$ Department of Pharmacy,University of Rajshahi, Rajshahi-6205, Bangladesh
}

Received: November 06, 2016; Accepted: November 27, 2016; Published (Web): March 19, 2017

\begin{abstract}
The main objective of the study was to evaluate the possible central nervous system (CNS) depressant and antinociceptive effects of methanol (MMPS), petroleum ether (PMPS), chloroform (CMPS), dichloromethane (DMPS) and aqueous (AMPS) extracts of the Microcos paniculata (M. paniculata). The CNS-depressant effect of different extracts of $M$. paniculata stem on Swiss albino mice was assessed by using open field, hole cross and head deep tests at 100 and $200 \mathrm{mg} / \mathrm{kg}$ dose. Analgesic effect was evaluated by acetic acid-induced writhing and hot plate methods at 100 and $200 \mathrm{mg} / \mathrm{kg}$ dose. All the extracts had exhibited significant $\left(\mathrm{P}^{\mathrm{b}}<0.01, \mathrm{P}^{\mathrm{a}}<0.001\right)$ CNS depressant and analgesic effects in a dose dependant manner. MMPS had shown highest CNSdepressant effect with $93.39 \%$ inhibition of mice movement (open field), $78.92 \%$ inhibition of hole cross and $86.90 \%$ inhibition of head deeping at $200 \mathrm{mg} / \mathrm{kg}$ dose. Besides, DMPS extracts showed maximum analgesic effect with $75.52 \%$ inhibition of abdominal writhing and $65.55 \%$ elongation of paw licking time at $200 \mathrm{mg} / \mathrm{kg}$ dose. Among the five extracts, MMPS possesses potent CNS depressant effect while DMPS possesses potent analgesic effect. These findings may expose effectiveness of the extracts on anxiety and pain that may help to formulate a herbal medicine or to search a lead compound.
\end{abstract}

Key words: Microcos paniculata; CNS-depressant effect; Traditional medicine; Analgesic effect; Writhing.

\section{Introduction}

Microcos paniculata L. is a herb or small tree and belongs to the tiliacece family. It is widely distributed in Bangladesh, India, Sri Lanka, China, Cambodia, Myanmar, Thailand, Vietnam, Indonesia and Malaysia. Locally it is called Kathgua or Fattashi in Bangladesh (Abdullah et al., 2013). It is used as a traditional medicine on hepatitis, diarrhea, dyspepsia, typhoid fever, small pox, eczema and itches. Alkaloids, flavonoids, resins, saponins, steroids and carbohydrates etc. bioactive chemicals have been reported in it (Arun et al., 2013).

Anxiety is responsible for obstacle of everyday life due to its involvement with fear, worry as well as restlessness of a person. It is associated with psychological and physiological state of the patient and is marked by cognitive, somatic, emotional and behavioral factors which provoke a disagreeable emotion (Xueli et al., 2014). Pain sensation, a noxious condition, often feels to a patient due to an array of ailment and some injurious conditions (Anamul et al., 2016). It is proved that the prolong use of synthetic drugs are harmful and very expensive for final development. These drugs have unpleasant side effects or toxic effects, and have failed to show a wide range of success against chronic diseases (Chandrashekara et al., 2002). For these reasons, the medical practitioners and the patients are frequently choosing the herbal products having novel bioactive agent(s) (Raman et al., 2013; Dayang et al., 2013). Inflammation and pain have long been treated with the traditional medicines, and often serve as a source of bioactive chemicals for the development of a new drug (Hwan-Suck et al., 2012). The present study was undertaken to investigate CNS

Correspondence to: Dr. Md. Anwar U1 Islam, E-mail: profanwarulislam@yahoo.com 
depressant and analgesic activity of methanol, petrolium ether, chloroform, dichloromethane and aqueous extracts of M. paniculata stem in Swiss albino mice that may unveil the rationality of use of the plant as traditional medicines and potentiality of it in the herbal medicine.

\section{Materials and Methods}

Plant materials: $M$. paniculata stem were collected from Comilla Hill tract, Bangladesh in September, 2014 and identified by an expert of the Bangladesh National Herbarium, Dhaka, where a voucher specimen has also been retained with accession no DACB-40638. The collected leaves were cleaned, dried for one week, and then pulverized into a coarse powder. The powder was stored in an airtight container and kept in a cool, dark, and dry place until further analysis was taken.

Extract preparation: Approximately $400 \mathrm{~g}$ of each powdered material was soaked in methanol, petroleum ether, chloroform, dichloromethane and water, and kept for 7 days. Then extraction was carried out using Ultrasonic Sound Bath accompanied by sonication. Then the mixture was firstly filtered by a piece of clean cotton material. The filtrate was again filtered through filter paper and was dried to obtain the methanol $(11.14 \mathrm{~g})$, petroleum ethar $(5.26 \mathrm{~g})$, chloroform $5.15 \mathrm{~g})$, dichloromethane $(4.75 \mathrm{~g})$, and aqueous $(7.30 \mathrm{~g})$ extracts. The gummy extracts were transferred to a closed container for further use and storage.

Drugs and chemicals: Methanol, petroleum ether, dichloromethane, chloroform, acetic acid and Tween-80 (Merck, Germany) were purchased from local market of Dhaka city, Bangladesh. Diazepam and dichlofenac sodium (DS) were collected from Square Pharmaceuticals Ltd. Bangladesh.

Animals: Swiss albino mice of either sex weighing approximately $25-30 \mathrm{~g}$ were used for this experiment. The mice were collected from the animal research branch of the International Centre for Diarrhoeal Disease and Research, Bangladesh. The set of rules for animal experiment were followed according to international guidelines (Zimmermann, 19836).

Evaluation of CNS depressant effect: This effect was evaluated by applying open field (Gupta et al.,
1971), hole cross (Takagi et al., 1971) and head deep (Dorr et al., 1971) tests. Shortly, 72 mice were divided into 12 groups and feed with vehicle ( $2 \%$ acacia), diazepam (2 mg/kg, b.w.), and the extracts (100 and $200 \mathrm{mg} / \mathrm{kg}$, b.w.) 30 minutes later, each mouse was placed in a open field box, a hole cross box, and a head deep box where number of mice movement (open field), passes through hole (hole cross) and head deeping were counted for 5 minutes at $0,30,60,90$, and 120 minutes of the experiment. Reduction of mice locomotion indicates CNS-depressant potential of the extracts. Percentage inhibition of locomotion was calculated at $120 \mathrm{~min}$ by the following formula: \% Inhibition $=\left[\left(\mathrm{N}_{0}-\mathrm{N}_{\mathrm{S}}\right) / \mathrm{N}_{0}\right] \times 100$, where, $\mathrm{N}_{0}$ is the average number of movements or passes or head deeping in control group and $\mathrm{N}_{\mathrm{S}}$ is the average number of movements or passes or head deeping in treated group (extract or standard drug).

Evaluation of analgesic effect: The analgesic effect was evaluated by using acetic acid-induced writhing and hot plate tests that were previously described by Koster et al. (Koster et al., 1959) as well as Eddy and Leimbach (Eddy and Leimbach, 1953), respectively. Briefly, 72 mice (Swiss albino) were divided into 12 groups. Then, mice of the specific group were feed with vehicle ( $2 \%$ acacia), diclofenac sodium $(10 \mathrm{mg} / \mathrm{kg})$, and the extracts (100 and $200 \mathrm{mg} / \mathrm{kg}$, b.w.) 30 minutes later, acetic acid-induced writhing response was counted for 20 minutes and heat-induced reaction time in hot plate (licking or jumping of mice) was measured at $0,30,60,90$ and 120 minutes of the experiment. Percent reduction of writhing, an index of analgesia, was calculated as: $\left[\left(\mathrm{N}_{\mathrm{c}}-\mathrm{N}_{\mathrm{t}}\right) / \mathrm{N}_{\mathrm{c}}\right] \times 100$, where, $\mathrm{N}_{\mathrm{c}}=$ writhing number of control group, $\mathrm{N}_{t}=$ writhing number of treated group. In the hot plate test, percentage of reaction time elongation was calculated as: $(\mathrm{Tc}-\mathrm{Ts}) / \mathrm{Tc} ; \mathrm{Tc}=$ reaction time of control group, $\mathrm{Ts}=$ reaction time of sample group.

Statistical analysis: All the values were expressed as the mean \pm SEM (Standard Error Mean) of triplicate experiment ( $\mathrm{n}=6$ mice per group). The analysis was done in SPSS statistical package, version 15.0. $\mathrm{P}^{\mathrm{b}}<0.01$, $\mathrm{P}^{\mathrm{a}}<0.001$ were considered to be statistically significant compared to vehicle control group. ANOVA followed by Dunnett 's test was done by the SPSS software. 


\section{Results}

CNS depression effect: All the extracts showed significant $\left(\mathrm{P}^{\mathrm{b}}<0.01, \mathrm{P}^{\mathrm{a}}<0.001\right)$ reduction of mice locomotion dose dependently. The standard drug diazepam $(2 \mathrm{mg} / \mathrm{kg})$ had shown $95.60 \%$ (open field test), $85.97 \%$ (hole cross test) and $90.43 \%$ (head deep test) inhibition of mice locomotion at the fifth observation. MMPS, among the five extracts, had shown maximum effect in all the three experiments, and PMPS had shown the lowest effect. After $120 \mathrm{~min}$ of treatment, the MMPS had shown $88.71 \%$ and $93.39 \%$ inhibition of movement in open field, $73.69 \%$ and $78.92 \%$ inhibition in hole cross as well as $81.55 \%$ and $86.90 \%$ inhibition in head deep test at 100 and 200 $\mathrm{mg} / \mathrm{kg}$ dose, respectively. The order of CNS depressant effect of the extracts in all the experiments was MMPS $>$ CMPS $>$ DMPS $>$ AMPS $>$ PMPS (Table-1, Table-2, Table-3).

Analgesic effect: All the extracts were significantly $\left(\mathrm{P}^{\mathrm{b}}<0.01, \mathrm{P}^{\mathrm{a}}<0.001\right)$ effective to reduce the writhing response, and to increase reaction time (licking or jumping of mice) as dose dependant manner. In writhing test, DS $(10 \mathrm{mg} / \mathrm{kg})$ showed $83.81 \%$ inhibition. DMPS, among the extracts, had shown the highest effect with $70.23 \%(100 \mathrm{mg} / \mathrm{kg})$ as well as $75.52 \%(200 \mathrm{mg} / \mathrm{kg})$ inhibition whereas MMPS had shown the lowest effect with $50.38 \%(100 \mathrm{mg} / \mathrm{kg})$ as well as $58.49 \%(200 \mathrm{mg} / \mathrm{kg})$ inhibition. In the hot plate test, DS had shown $63.95 \%, 67.30 \%, 70.86 \%$ and $68.49 \%$ elongation of response time. Among the five extracts, DMPS had shown the highest effect with $55.23 \%, 61.14 \%, 65.55 \%$ and $60.75 \%$ elongation at 30 , $60,90,120$ minute respectively. The order of writhing inhibition and elongation of response time is DS> DMPS $>$ CMPS $>$ AMPS $>$ MMPS $>$ PMPS (Table-4, Table-5).

\section{Discussion}

Plant has a great impact on the discovery of drug because of bioactive lead compounds in it. As a medicine, it is being used from the ancient time to cure diseases for its availability, less side effects and cheap. So, it is very important to introduce a new plant as a source of medicine (Mahfuza et al., 2014). Open field, hole cross and head deep tests (locomotor test) are widely applied to evaluate CNS depressant potential of an agent. These tests evaluates index of alertness and a reduction of it is an indicative of sedative or CNS depressant activity (Protapaditya et al., 2011). Gammaaminobutyric acid (GABA) is the major inhibitory neurotransmitter in the CNS (Kavita et al., 2013). Various drugs such as anxiolytic, muscle relaxant and sedative-hypnotic acts via the GABA.

Table 1. CNS depressant effect of different extracts of $M$. paniculata stem at open field test.

\begin{tabular}{lccccccc}
\hline Sample & $\begin{array}{c}\text { Dose } \\
\mathrm{mg} / \mathrm{kg}, \\
\text { b.w. }\end{array}$ & $0 \mathrm{~min}$ & $30 \mathrm{~min}$ & $60 \mathrm{~min}$ & $90 \mathrm{~min}$ & $120 \mathrm{~min}$ & $\begin{array}{c}\text { \% Inhibition of } \\
\text { movements } \\
\text { after 120 min }\end{array}$ \\
\cline { 3 - 7 } Control & $0.1 \mathrm{ml}$ & $250.12 \pm 12.36$ & $242.45 \pm 13.22$ & $238.51 \pm 13.25$ & $235.60 \pm 15.2225$ & $233.21 \pm 14.44$ & -- \\
Diazepam & 2 & $245.45 \pm 14.36$ & $152.36 \pm 15.33^{\mathrm{a}}$ & $43.30 \pm 12.10^{\mathrm{a}}$ & $16.22 \pm 1.32^{\mathrm{a}}$ & $10.25 \pm 1.23^{\mathrm{a}}$ & 95.60 \\
MMPS & 100 & $260.69 \pm 14.96$ & $185.58 \pm 12.42^{\mathrm{b}}$ & $76.24 \pm 9.20^{\mathrm{a}}$ & $36.62 \pm 2.45^{\mathrm{a}}$ & $26.32 \pm 2.47^{\mathrm{a}}$ & 88.71 \\
& 200 & $243.45 \pm 13.17$ & $170.25 \pm 13.25^{\mathrm{a}}$ & $62.46 \pm 8.23^{\mathrm{a}}$ & $25.24 \pm 2.13^{\mathrm{a}}$ & $15.41 \pm 1.23^{\mathrm{a}}$ & 93.39 \\
PMPS & 100 & $252.21 \pm 16.20$ & $212.34 \pm 16.25^{\mathrm{b}}$ & $101.20 \pm 10.23^{\mathrm{a}}$ & $76.36 \pm 3.42^{\mathrm{a}}$ & $66.62 \pm 3.47^{\mathrm{a}}$ & 71.43 \\
& 200 & $259.52 \pm 15.47$ & $199.17 \pm 12.52^{\mathrm{b}}$ & $96.60 \pm 9.41^{\mathrm{a}}$ & $63.47 \pm 3.23^{\mathrm{a}}$ & $52.50 \pm 3.28^{\mathrm{a}}$ & 77.48 \\
CMPS & 100 & $256.36 \pm 13.25$ & $193.12 \pm 14.27^{\mathrm{b}}$ & $80.25 \pm 10.32^{\mathrm{a}}$ & $46.12 \pm 3.22^{\mathrm{a}}$ & $32.39 \pm 2.15^{\mathrm{a}}$ & 86.11 \\
& 200 & $248.14 \pm 15.36$ & $182.40 \pm 12.42^{\mathrm{b}}$ & $74.17 \pm 8.12^{\mathrm{a}}$ & $38.36 \pm 2.55^{\mathrm{a}}$ & $20.75 \pm 2.36^{\mathrm{a}}$ & 91.10 \\
DMPS & 100 & $247.87 \pm 10.23$ & $201.36 \pm 14.32^{\mathrm{b}}$ & $90.23 \pm 8.25^{\mathrm{a}}$ & $57.32 \pm 4.17^{\mathrm{a}}$ & $39.27 \pm 3.49^{\mathrm{a}}$ & 83.16 \\
& 200 & $253.17 \pm 14.24$ & $188.24 \pm 15.26^{\mathrm{b}}$ & $81.24 \pm 10.36^{\mathrm{a}}$ & $44.24 \pm 3.22^{\mathrm{a}}$ & $28.88 \pm 2.10^{\mathrm{a}}$ & 87.62 \\
AMPS & 100 & $246.58 \pm 13.25$ & $208.69 \pm 10.32^{\mathrm{b}}$ & $98.52 \pm 9.12^{\mathrm{a}}$ & $60.45 \pm 4.18^{\mathrm{a}}$ & $41.36 \pm 3.27^{\mathrm{a}}$ & 82.26 \\
& 200 & $256.47 \pm 11.20$ & $192.70 \pm 16.25^{\mathrm{b}}$ & $85.36 \pm 7.12^{\mathrm{a}}$ & $47.78 \pm 3.23^{\mathrm{a}}$ & $34.95 \pm 3.56^{\mathrm{a}}$ & 85.01 \\
\hline
\end{tabular}


Table 2. CNS depressant effect of different extracts of M. paniculata stem at hole cross test.

\begin{tabular}{lccccccc}
\hline Sample & $\begin{array}{c}\text { Dose } \\
\mathrm{mg} / \mathrm{kg}, \mathrm{b} . \mathrm{w} .\end{array}$ & $0 \mathrm{~min}$ & $30 \mathrm{~min}$ & $60 \mathrm{~min}$ & $90 \mathrm{~min}$ & $120 \mathrm{~min}$ & $\begin{array}{c}\text { \% Inhibition } \\
\text { after 120 min }\end{array}$ \\
\cline { 3 - 6 } Control & $0.1 \mathrm{ml}$ & $15.69 \pm 3.21$ & $14.20 \pm 1.11$ & $14.16 \pm 1.42$ & $13.82 \pm 2.19$ & $13.19 \pm 2.45$ & - \\
Diazepam & 2 & $14.23 \pm 2.15$ & $4.32 \pm 0.47^{\mathrm{a}}$ & $3.90 \pm 0.28^{\mathrm{a}}$ & $2.10 \pm 0.25^{\mathrm{a}}$ & $1.85 \pm 0.01^{\mathrm{a}}$ & 85.97 \\
MMPS & 100 & $15.36 \pm 2.78$ & $8.20 \pm 1.36^{\mathrm{a}}$ & $7.36 \pm 1.47^{\mathrm{a}}$ & $5.20 \pm 0.58^{\mathrm{a}}$ & $3.47 \pm 0.20^{\mathrm{a}}$ & 73.69 \\
& 200 & $14.35 \pm 3.10$ & $6.32 \pm 1.10^{\mathrm{a}}$ & $4.60 \pm 1.35^{\mathrm{a}}$ & $3.14 \pm 0.45^{\mathrm{a}}$ & $2.78 \pm 0.25^{\mathrm{a}}$ & 78.92 \\
\multirow{2}{*}{ PMPS } & 100 & $14.15 \pm 1.89$ & $10.87 \pm 2.37^{\mathrm{b}}$ & $9.25 \pm 1.24^{\mathrm{a}}$ & $7.95 \pm 1.47^{\mathrm{a}}$ & $7.12 \pm 1.23^{\mathrm{a}}$ & 46.02 \\
& 200 & $16.90 \pm 1.60$ & $9.90 \pm 2.78^{\mathrm{a}}$ & $8.20 \pm 1.47^{\mathrm{a}}$ & $7.23 \pm 1.69^{\mathrm{a}}$ & $5.80 \pm 0.47^{\mathrm{a}}$ & 56.03 \\
CMPS & 100 & $16.25 \pm 2.47$ & $9.12 \pm 2.47^{\mathrm{a}}$ & $7.20 \pm 1.34^{\mathrm{a}}$ & $5.45 \pm 0.41^{\mathrm{a}}$ & $4.30 \pm 0.25^{\mathrm{a}}$ & 67.40 \\
& 200 & $17.47 \pm 2.33$ & $7.36 \pm 1.78^{\mathrm{a}}$ & $6.25 \pm 0.58^{\mathrm{a}}$ & $4.36 \pm 0.32^{\mathrm{a}}$ & $3.12 \pm 0.18^{\mathrm{a}}$ & 76.35 \\
DMPS & 100 & $15.30 \pm .1 .23$ & $9.58 \pm 1.90^{\mathrm{a}}$ & $7.50 \pm 1.12^{\mathrm{a}}$ & $6.10 \pm 0.58^{\mathrm{a}}$ & $5.10 \pm 0.45^{\mathrm{a}}$ & 61.33 \\
& 200 & $13.00 \pm 1.47$ & $8.26 \pm 1.47^{\mathrm{a}}$ & $6.80 \pm 1.21^{\mathrm{a}}$ & $5.20 \pm 0.45^{\mathrm{a}}$ & $3.95 \pm 0.25^{\mathrm{a}}$ & 70.05 \\
\multirow{2}{*}{ AMPS } & 100 & $14.15 \pm 1.15$ & $10.20 \pm 2.12^{\mathrm{b}}$ & $8.65 \pm 1.24^{\mathrm{a}}$ & $7.36 \pm 1.14^{\mathrm{a}}$ & $6.45 \pm 1.23^{\mathrm{a}}$ & 51.10 \\
& 200 & $13.36 \pm 1.69$ & $8.75 \pm 1.65^{\mathrm{a}}$ & $7.10 \pm 1.22^{\mathrm{a}}$ & $6.12 \pm 0.54^{\mathrm{a}}$ & $5.20 \pm 0.57^{\mathrm{a}}$ & 60.58 \\
\hline
\end{tabular}

Table 3. CNS depressant effect of different extracts of $M$. paniculata stem at head deep test.

\begin{tabular}{|c|c|c|c|c|c|c|c|}
\hline \multirow[t]{2}{*}{ Sample } & \multirow{2}{*}{$\begin{array}{c}\text { Dose } \\
\mathrm{mg} / \mathrm{kg} \text {, b.w. }\end{array}$} & \multicolumn{5}{|c|}{ Number of head deeping } & \multirow{2}{*}{$\begin{array}{l}\% \text { Inhibition } \\
\text { after } 120 \mathrm{~min}\end{array}$} \\
\hline & & $0 \min$ & $30 \mathrm{~min}$ & $60 \mathrm{~min}$ & $90 \mathrm{~min}$ & $120 \mathrm{~min}$ & \\
\hline Control & $0.1 \mathrm{ml}$ & $94.23 \pm 7.23$ & $92.12 \pm 9.23$ & $90.36 \pm 9.14$ & $89.47 \pm 8.19$ & $87.39 \pm 6.12$ & -- \\
\hline Diazepam & 2 & $91.65 \pm 6.45$ & $35.47 \pm 8.25^{\mathrm{a}}$ & $21.29 \pm 2.45^{\mathrm{a}}$ & $14.20 \pm 1.40^{\mathrm{a}}$ & $8.36 \pm 1.11^{\mathrm{a}}$ & 90.43 \\
\hline \multirow[t]{2}{*}{ MMPL } & 100 & $88.56 \pm 6.49$ & $45.32 \pm 4.28^{\mathrm{a}}$ & $32.17 \pm 3.24^{\mathrm{a}}$ & $23.14 \pm 2.38^{\mathrm{a}}$ & $16.12 \pm 1.21^{\mathrm{a}}$ & 81.55 \\
\hline & 200 & $85.41 \pm 8.30$ & $41.69 \pm 4.12^{\mathrm{a}}$ & $26.36 \pm 2.47^{\mathrm{a}}$ & $18.62 \pm 1.69^{\mathrm{a}}$ & $11.45 \pm 1.30^{\mathrm{a}}$ & 86.90 \\
\hline \multirow[t]{2}{*}{ PMPL } & 100 & $87.25 \pm 7.13$ & $65.23 \pm 6.20^{\mathrm{a}}$ & $51.23 \pm 5.12^{\mathrm{a}}$ & $46.89 \pm 4.23^{\mathrm{a}}$ & $39.17 \pm 3.29^{\mathrm{a}}$ & 55.18 \\
\hline & 200 & $89.17 \pm 9.12$ & $55.69 \pm 5.14^{\mathrm{a}}$ & $44.60 \pm 4.37^{\mathrm{a}}$ & $37.18 \pm 3.47^{\mathrm{a}}$ & $34.68 \pm 3.24^{\mathrm{a}}$ & 60.32 \\
\hline \multirow[t]{2}{*}{ CMPL } & 100 & $88.47 \pm 7.12$ & $51.60 \pm 7.14^{\mathrm{a}}$ & $34.38 \pm 3.26^{\mathrm{a}}$ & $28.29 \pm 2.30^{\mathrm{a}}$ & $20.23 \pm 2.14^{\mathrm{a}}$ & 76.85 \\
\hline & 200 & $87.69 \pm 8.33$ & $44.56 \pm 4.57^{\mathrm{a}}$ & $27.14 \pm 2.47^{\mathrm{a}}$ & $19.47 \pm 1.25^{\mathrm{a}}$ & $15.47 \pm 1.29^{\mathrm{a}}$ & 82.30 \\
\hline \multirow[t]{2}{*}{ DMPL } & 100 & $87.32 \pm 10.23$ & $56.45 \pm 6.35^{\mathrm{a}}$ & $37.36 \pm 3.58^{\mathrm{a}}$ & $32.56 \pm 3.21^{\mathrm{a}}$ & $26.28 \pm 2.28^{\mathrm{a}}$ & 69.93 \\
\hline & 200 & $90.25 \pm 12.20$ & $48.37 \pm 4.78^{\mathrm{a}}$ & $31.89 \pm 3.20^{\mathrm{a}}$ & $25.47 \pm 2.65^{\mathrm{a}}$ & $21.72 \pm 2.18^{\mathrm{a}}$ & 75.15 \\
\hline \multirow[t]{2}{*}{ AMPL } & 100 & $90.47 \pm 9.25$ & $60.14 \pm 6.25^{\mathrm{a}}$ & $46.15 \pm 4.10^{\mathrm{a}}$ & $38.29 \pm 3.47^{\mathrm{a}}$ & $33.12 \pm 3.20^{\mathrm{a}}$ & 62.12 \\
\hline & 200 & $92.64 \pm 7.44$ & $53.85 \pm 5.17^{\mathrm{a}}$ & $36.17 \pm 3.26^{\mathrm{a}}$ & $29.14 \pm 2.12^{\mathrm{a}}$ & $28.45 \pm 2.48^{\mathrm{a}}$ & 67.44 \\
\hline
\end{tabular}

Sedative agents may give the CNS depressant effect through modification of the GABA system where modification may take place by potentiating postsynaptic inhibition of the GABA receptors and elevating the GABA-induced chloride conductance with simultaneous depression of voltage activated $\mathrm{Ca}^{++}$ currents (Uma et al., 2011).

Therefore, it is predictable that the extracts may act by potentiating GABAergic inhibition in the CNS via membrane hyper-polarization leading to a reduction in the firing rate of critical neurons in the brain (Kavita et al., 2013). The locomotor tests have shown that all doses of the extracts significantly $\left(\mathrm{p}^{\mathrm{b}}<0.01, \mathrm{p}^{\mathrm{a}}<\right.$ 0.001 ) reduced the frequency and the amplitude of movements in dose dependant manner from the second observation $(30 \mathrm{~min})$ and continued up to the fifth observation (120 min) period (Tables 1-3) which may be due to the presence of compound(s) having CNS depressant potential. 
Pain is associated with many diseases and several natural products are used to relieve pain and inflammation. Abdominal writhing mediates via local peritoneal receptor. Intraperitonial injection of acetic acid induces capillary permeability that promotes generation of pain sensitive prostaglandin specifically PGE2 and PGF2 $\alpha$, and release of free arachidonic acid, an endogenous inflammatory substance, from tissue phospholipids by the action of cyclo-oxygenase (COX) enzyme (Chandana et al., 2011). Substance(s) inhibiting the writhing response may have analgesic effect preferably by inhibition of prostaglandin synthesis (Luiz et al., 2012). Non steroidal antiinflammatory drugs (NSAIDs) inhibit COX in peripheral tissues, and therefore interfere with the pain sensation. The extracts could block the pain inducing endogenous substances similar to that of NSAIDs

Table 4. Analgesic effect of M. paniculata stem extracts in acetic acid-induced writhing test.

\begin{tabular}{lccc}
\hline Sample & $\begin{array}{c}\text { Dose } \\
\mathrm{mg} / \mathrm{kg}, \mathrm{b} . \mathrm{w} .\end{array}$ & Writhing number & $\begin{array}{c}\text { Percent inhibition of } \\
\text { writhing }\end{array}$ \\
\hline Control(vehicle) & $0.1 \mathrm{ml} / \mathrm{mice}$ & $52.20 \pm 4.26$ & 00 \\
DS & $10 \mathrm{mg} / \mathrm{kg}$ & $8.45 \pm 1.10^{\mathrm{a}}$ & 83.81 \\
& 100 & $25.90 \pm 2.47^{\mathrm{a}}$ & 50.38 \\
MMPS & 200 & $21.67 \pm 3.21^{\mathrm{a}}$ & 58.49 \\
& 100 & $35.6 \pm 3.77^{\mathrm{a}}$ & 31.80 \\
PMPS & 200 & $30.54 \pm 2.18^{\mathrm{a}}$ & 41.49 \\
& 100 & $15.54 \pm 1.52^{\mathrm{a}}$ & 70.23 \\
DMPS & 200 & $12.78 \pm 1.25^{\mathrm{a}}$ & 75.52 \\
& 100 & $20.65 \pm 2.34^{\mathrm{a}}$ & 60.44 \\
CMPS & 200 & $14.22 \pm 1.90^{\mathrm{a}}$ & 72.76 \\
& 100 & $23.40 \pm 2.48^{\mathrm{a}}$ & 55.17 \\
AMPS & 200 & $16.70 \pm 2.78^{\mathrm{a}}$ & 72.92 \\
\hline
\end{tabular}

Table 5. Analgesic effect of $M$. paniculata stem extracts in hot plate test.

\begin{tabular}{ccccccc}
\hline Sample & $\begin{array}{c}\text { Dose } \\
\mathrm{mg} / \mathrm{kg}, \\
\text { b.w. }\end{array}$ & $0 \mathrm{~min}$ & $30 \mathrm{~min}$ & $60 \mathrm{~min}$ & $90 \mathrm{~min}$ & $120 \mathrm{~min}$ \\
\hline Vehicle & $0.1 \mathrm{ml}$ & $5.36 \pm 0.15$ & $5.48 \pm 0.28$ & $5.98 \pm 0.35$ & $6.47 \pm 0.25$ & $6.10 \pm 0.31$ \\
DS & 10 & $6.55 \pm 0.32$ & $15.20 \pm 1.44^{\mathrm{a}}(63.95)$ & $18.29 \pm 2.10^{\mathrm{a}}(67.30)$ & $22.28 \pm 2.68^{\mathrm{a}}(70.86)$ & $19.34 \pm 2.25^{\mathrm{a}}(68.46)$ \\
& 100 & $4.85 \pm 0.12$ & $6.10 \pm 0.15(10.16)$ & $7.86 \pm 0.17^{\mathrm{b}}(23.92)$ & $9.25 \pm 1.12^{\mathrm{a}}(30.05)$ & $7.26 \pm 0.26^{\mathrm{b}}(15.98)$ \\
MMPS & 200 & $5.57 \pm 0.66$ & $8.43 \pm 0.87^{\mathrm{a}}(34.99)$ & $9.96 \pm 0.38^{\mathrm{a}}(39.96)$ & $13.89 \pm 0.12^{\mathrm{a}}(53.42)$ & $10.87 \pm 3.76^{\mathrm{a}}(43.88)$ \\
& 100 & $5.25 \pm 0.30$ & $5.75 \pm 0.11(4.70)$ & $6.35 \pm 0.28(5.83)$ & $7.36 \pm 0.38^{\mathrm{b}}(12.09)$ & $6.52 \pm 0.25(6.44)$ \\
PMPS & 200 & $5.42 \pm 0.40$ & $6.62 \pm 0.42^{\mathrm{b}}(17.22)$ & $7.23 \pm 0.68^{\mathrm{b}}(17.29)$ & $9.36 \pm 0.47^{\mathrm{a}}(30.88)$ & $7.89 \pm 0.21^{\mathrm{b}}(22.69)$ \\
& 100 & $6.12 \pm 0.32$ & $10.48 \pm 1.16^{\mathrm{a}}(47.71)$ & $13.45 \pm 1.35^{\mathrm{a}}(55.54)$ & $15.36 \pm 1.61^{\mathrm{a}}(57.88)$ & $12.36 \pm 0.68^{\mathrm{a}}(50.65)$ \\
DMPS & 200 & $6.35 \pm 0.34$ & $12.24 \pm 1.37^{\mathrm{a}}(55.23)$ & $15.39 \pm 1.62^{\mathrm{a}}(61.14)$ & $18.78 \pm 2.55^{\mathrm{a}}(65.55)$ & $15.54 \pm 2.70^{\mathrm{a}}(60.75)$ \\
& 100 & $5.38 \pm 0.36$ & $9.58 \pm 0.80^{\mathrm{a}}(42.80)$ & $11.28 \pm 1.26^{\mathrm{a}}(46.99)$ & $13.69 \pm 2.15^{\mathrm{a}}(52.74)$ & $10.23 \pm 1.26^{\mathrm{a}}(40.37)$ \\
CMPS & 200 & $6.20 \pm 0.22$ & $11.25 \pm 0.58^{\mathrm{a}}(51.29)$ & $13.47 \pm 0.62^{\mathrm{a}}(55.61)$ & $16.32 \pm 1.48^{\mathrm{a}}(60.36)$ & $13.36 \pm 1.92^{\mathrm{a}}(54.34)$ \\
& 100 & $5.58 \pm 0.32$ & $7.56 \pm 0.28^{\mathrm{b}}(27.51)$ & $9.36 \pm 0.16^{\mathrm{a}}(36.11)$ & $11.55 \pm 1.38^{\mathrm{a}}(43.98)$ & $8.36 \pm 0.65^{\mathrm{a}}(27.03)$ \\
AMPS & 200 & $5.26 \pm 0.45$ & $10.53 \pm 1.56^{\mathrm{a}}(47.96)$ & $12.28 \pm 1.59 \mathrm{a}(51.30)$ & $14.16 \pm 3.68^{\mathrm{a}}(54.31)$ & $12.33 \pm 2.81^{\mathrm{a}}(50.53)$ \\
\hline
\end{tabular}

(Chandana et al., 2011). The hot plate method can evaluate centrally acting analgesic properties of a drugs or chemicals. Heat induces pain sensation through opioid receptors. So, the agent that elongates reaction time in the hot plate test, acts through the opioid receptors and called centrally acting analgesics 
(Moniruzzaman and Mohammad, 2014) Thus, the significant $\left(\mathrm{p}^{\mathrm{a}}<0.001\right)$ reduction of acetic acid-induced writhing (Table-4), and elongation of reaction time in hot plate test (Table-5) indicates the peripherally and centrally acting analgesic effect of the extracts, respectively.

Natural products like alkaloids, flavonoids and tannins are potent analgesic compounds. Flavanoids exert their effect through inhibition of prostaglandin synthatase (Mojahid-Ul and Sanadel, 2012). Various flavonoid derivatives including quercetin have inhibitory effect of arachidonic acid metabolizing enzymes (phospholipase $\mathrm{A}_{2}$, cycloxygenase and lipoxygenase). Several phytochemicals like flavonoids, saponins and tannins etc have CNS depressant effect. Many flavonoids and neuroactive steroids are ligands for $\mathrm{GABA}_{\mathrm{A}}$ receptors in the central nervous system which suggests that they can act as benzodiazepine-like agents (Protapaditya et al., 2011). Literature review of the plant has revealed alkaloids, flavonoids, resins, saponins, steroids, stigmasterol, triterpene, and epicatechin in it. These agents may be responsible for the analgesic and CNS-depressant effects of the plant (Arun et al., 2013)

\section{Conclusion}

M. paniculata is long been used as traditional medicine against various diseases. Methanol, petroleum ether, chloroform, dichloromethane and aqueous extracts of its stem were evaluated on mice locomotion (using open field, hole cross and head deep test) and pain (induced by acetic acid and heat). All the extracts had shown CNS depressant and antinociceptive effects. But the methanol (MMPS) and dichloromethane (DMPS) extracts had shown potent CNS depressant and antinociceptive effects, respectively. However, further study is necessary to find out the main bioactive compounds responsible for the effects.

\section{Acknowledgments}

Authors are grateful to Md. Saddam Hossain, Md. Kawser Hamid, Arnab Chakma, Md. Golam Azom and Parvez Ahmed, students of Pharmacy department(20132014 session), Comilla University for helping the authors during the study period.
Conflict of interest: Author has no conflict of interest.

\section{References}

Abdullah, A.M., Mohammad Mahfuz, A.K.S., Shahariar, R., Tariqul, I., Mohoni, M., Abdullah, F. and sohel, R.M. 2013. Secondary metabolites, antimicrobial, brine shrimp lethality \& 4th instar Culex quinquefasciatus mosquito larvicidal screening of organic \& inorganic root extracts of Microcos paniculata. IOSR J. Phar. Biol. Sci. 8, 58-65.

Anamul, H., Rajashree, C., Banolata, S., Shahin, M., HasibAl-Mahfuj, Raihan, S., Monjur-Al- Hossain, A.S.M. 2016. Antinociceptive, anti-Inflammatory and central nervous system depressant activities of crude methanol extract and its dichloromethane, chloroform and aqueous fractions of Scurrula parasitica (Linn.) leaves. J. Pharmacog. Phytochem. 5, 93-98.

Arun, J., Maya, B. and Ashma, S. 2013. Phytochemical investigation of the roots of Grewiamicrocos Linn. J. Chem. Phar. Res. 5(7), 80-87.

Chandana, C.B., Jayanti, D.R., Bhaben, B., Acheenta, G.B., Prabodh, B. and Mangala, L. 2011. Analgesic and antinociceptive activity of hydroethanolic extract of Drymaria cordata willd. Indian J. Pharmacol. 43, 121125.

Chandrashekara, S., Anilkumar, T., and Jamuna, S. 2002. Complementary and alternative drug therapy in arthritis. J. Asso. Physi. India. 50, 225-227.

Dayang, E.Z., Awang, H., Roslida, A.H., Latifah, S.Y., Che, N.M.T., and Yeong, L.T. 2013. The hexane fraction of Ardisia crispa Thunb. A.DC.roots inhibits inflammation-induced angiogenesis. BMC Complemen. Altern. Med. 13, 5-12.

Dorr, M., Stienberg, H., Tomkiewiez, M., Joyee, D., Porosolt, R.D. and Summerfield, A. 1971. Persistence of dose related behavior in mice. Nature. 231, 121-123.

Eddy, N.B., and Leimbach, D. 1953. Synthetic analgesics: II. Dithienylbutenyl and Dithienylbutylamines. $J$. Pharmacol experi. Therap. 107, 385-393.

Gupta, B.D., Dandiya, P.C. and Gupta, M.L. 1971. A psychopharmacological analysis of behaviour in rats. Japanese J. Pharmacol. 21, 293-298.

Hwan-Suck, C., Hye, J.L., Insop, S., and Hyunsu, B. 2012. Assessment of anti-depressant effect of nelubinissemen on rats under chronic mild stress and its subchronic oral toxicity in rats and beagle dogs. BMC Complement Altern Med. 12, 68-65.

Kavita, G., Vijay, K.L. and Shivesh, J. 2013. Anticonvulsant potential of ethanol extracts and their solvent partitioned fractions from Flemingia strobilifera root. Pharmacog. Res. 5, 265-270. 
Koster, R., Anderson, M. and Debeer, E.J. 1959. Acetic acid for analgesic screening. Fed. Proc. 18, 412-416.

Luiz, H.A. C., Brito, M.C.B, Araújo, M.V., Barbosa-Filho, J.M., Lira, D.P. and Oliveira, S.B.V. 2012. Antinociceptive and anti-inflammatory activities of crude methanolic extract of red alga Bryothamnion triquetrum. Marine Drugs. 10, 1977-1992.

Mahfuza, K., Hajera, K., Ekramul, I., and Shahnaj, P. 2014. Analgesic, antibacterial and central nervous system depressant activities of Albizia procera leaves. Asian Pac. J. Trop. Biomed. 4, 279-284.

Mojahid-Ul, I. and Sanadel, A.E. 2012. Phytrochemical investigation and evaluation of analgesic activity of ethanolic extract of delbergia sisso (Roxb) bark. J Nat. Prod. Plant Res. 2, 701-704

Moniruzzaman, M. and Mohammad, Z.I. 2014. Evaluation of antinociceptive effect of methanolic extract of leaves of Crataeva nurvala Buch.-Ham. BMC Complement. Altern. Med. 14, 354-362.

Protapaditya, D., Sangita, C., Priyanka, C. and Sanjib, B. 2011. Neuropharmacological properties of Mikania scandens (L.) Willd. (Asteraceae). J. Advan. Pharm. Tech. Res. 2, 255-259.
Raman, C., Pallavi, T., Ayush, C., Sarita, J., Anamika, S., Rajeev, G, Jyoti, S., Smruti, S.P.,Vinod, K., Rakesh, K.S., and Rajesh, A. 2013. Evidence based herbal drug standardization approach in coping with challenges of holistic management of diabetes: a dreadful lifestyle disorder of 21 st century. J. Diabetes Meta. Dis. 12, 35-41.

Takagi, K., Watanabe, M. and Saito, H. 1971. Studies of the spontaneous movement of animals by the hole cross test; effect of 2-dimethyl-aminoethanol and its acyl esters on the central nervous system. Japan. J. Pharmacol. 21, 797-810.

Uma, A.B., Radha, Y., Prachi, D.P., Mandar, R.Z. and Raul, S.S. 2011. Study of central nervous system depressant and behavioral activity of an ethanol extract of Achyranthes aspera (Agadha) in different animal models. Int. J. App. Basic Med. Res. 1(2), 104-108.

Xueli, Z., Yang, Y., Zhou, C., Shan, L., Yunguo, Z. and Xiaoling Y. 2014. Anti-depressant effect of Chimonanthus salicifolicus essential oil in chronic stressed rats. J Medi. Plant Res. 8, 430-435.

Zimmermann, M. 1983. Ethical guidelines for investigations of experimental pain in concious animals. Pain. 16, 109110. 